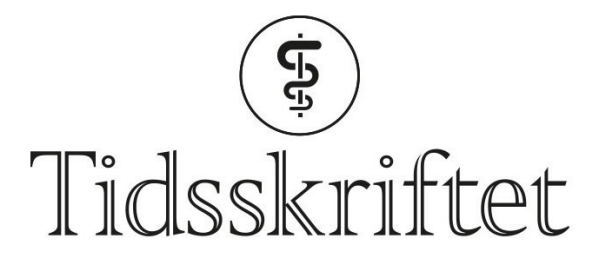

DEN NORSKE LEGEFORENING

\title{
Forside nr. 14/2019
}

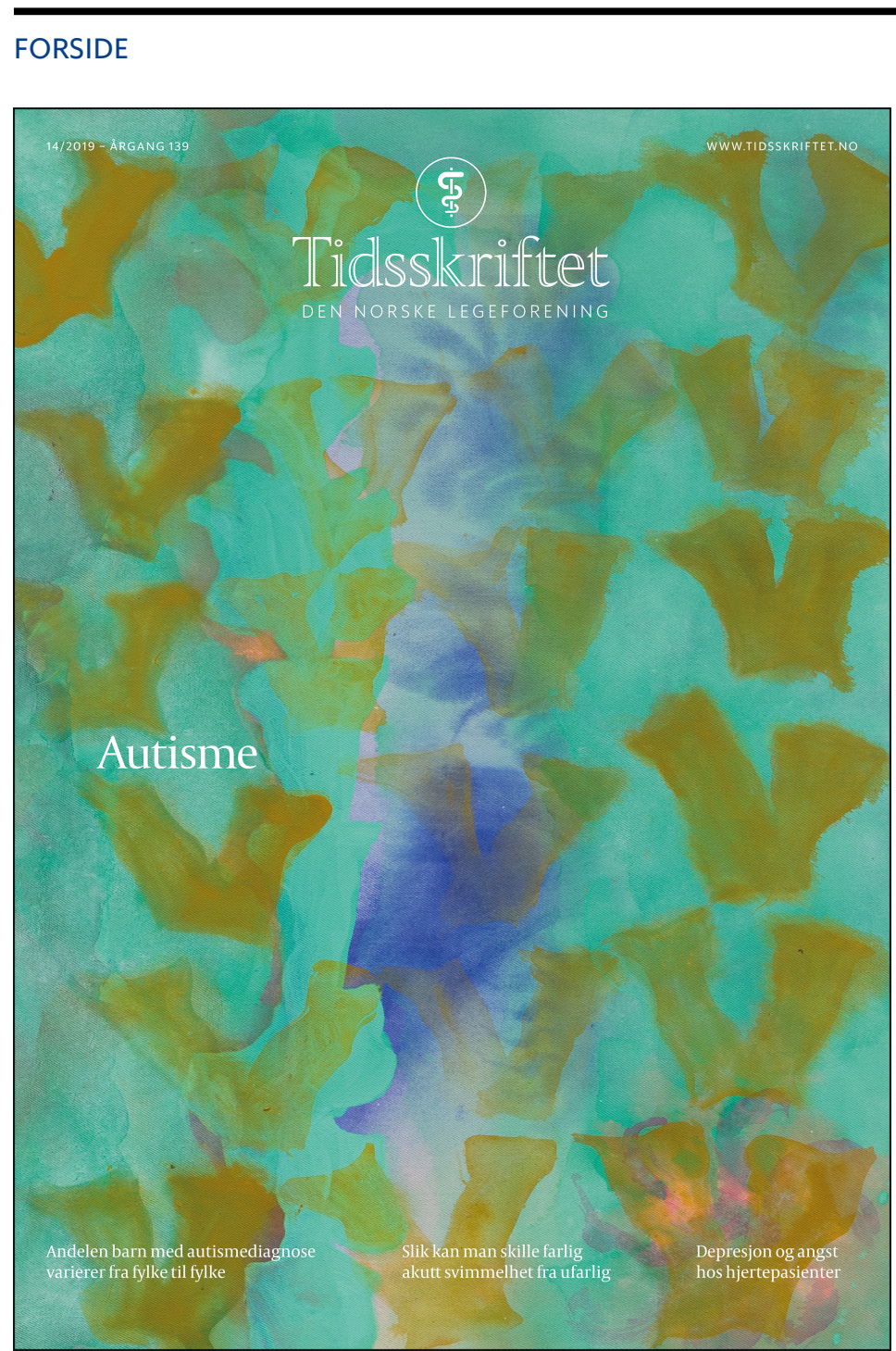

Illustrasjon (C) Marianne Hurum

Mønstergjenkjenning er sentralt når hjernen skal prosessere visuell informasjon om for eksempel et ansikt. På et brøkdels sekund vet vi om den vi møter er ung eller gammel, sint eller glad. Barn med autismespekterforstyrrelser kan ha vansker med å tolke ansiktsuttrykk. Sosialt samspill krever dermed mye av barnet. Når man må bruke mye krefter på det som for andre barn går automatisk, er det kanskje ikke så rart om man liker best at det er struktur og orden rundt seg og at alle lekebilene står på rekke?

Å sette diagnoser handler også om mønstergjenkjenning. I dette nummeret har vi en originalartikkel om fylkesvise forskjeller i diagnostisering av autismespekterforstyrrelser hos barn. 
- Maleriet på forsiden har et repetitivt mønster av en V-form og en rolig, blå farge man kan se inn til i midten av bildet. Jeg tenker på motsetningsparet orden og kaos, sier Marianne Hurum, kunstneren bak forsiden.

Se flere av Mariannes arbeider på www.mariannehurum.com/

Publisert: 7. oktober 2019. Tidsskr Nor Legeforen. DOI: 10.4045/tidsskr.19.14.02

(C) Tidsskrift for Den norske legeforening 2020. Lastet ned fra tidsskriftet.no 